\title{
ORGANIC AGRICULTURE AS AN INDICATOR OF SUSTAINABLE AGRICULTURAL DEVELOPMENT: SERBIA IN FOCUS
}

\author{
Mirela Tomaš Simin ${ }^{1}$, Vesna Rodić ${ }^{2}$, Danica Glavaš-Trbić ${ }^{3}$ \\ *Corresponding author E-mail: mirela.tomas@polj.edu.rs
}

A R T I C L E I N F O
Review Article
Received: 28 November 2018
Accepted: 14 March 2019
doi:10.5937/ekoPolj1901265T
UDC
631.147:502.131.1(497.11)

Keywords:

Organic agriculture, sustainable development, indicators, Republic of Serbia

JEL: Q00, Q01, Q15, Q56

\section{A B S T R A C T}

Sustainable development is a concept which has not yet been uniquely defined at the international level. As a result, it is difficult to define the indicators which could "measure" the achievement of sustainability. The paper deals with organic agriculture as a commonly used indicator of sustainable agricultural development. The organic farming in Serbia is legally a well-regulated area, but still not developed to the necessary and possible extent. Following the practice of the most developed countries, the area under organic production is distinguished as one of the indicators in the National List of Indicators for Sustainable Development of the Republic of Serbia. Nowadays, organic farming occupies only about $0.45 \%$ of total UAA in Serbia (approx 15,000 ha), which is relatively low in comparison with the EU countries. Therefore, the development of Serbian agriculture cannot be assessed as sustainable. Although the authors of this paper support the use of organic agriculture as an indicator of agricultural sustainability, they endorse it in conjunction with other indicators in the matter, whenever possible

(C) 2019 EA. All rights reserved.

\section{Introduction}

Sustainable development is a concept that has not yet been unambiguously defined, despite a decades-long discussion in the relevant literature (Lele, 1991, Bell and Morse, 2003, Kates et al, 2005, UNEP, 2015). A definition most often used in the literature is from 1987, provided by The Brundtland Commission, by which sustainable development is "... a set of activities that allow meeting the needs of today without compromising the possibilities of future generations to meet their own needs" (UN, 1987). The National

1 MSc Mirela Tomaš Simin, teaching assitant, Faculty of Agriculture Novi Sad, Trg Dositeja Obradovića 8, 21000 Novi Sad, +381214853514, mirela.tomas@polj.edu.rs, ORCID ID (https://orcid.org/0000-0003-1833-9857)

2 PhD Vesna Rodić, full prof., Faculty of Agriculture Novi Sad, Trg Dositeja Obradovića 8, 21000 Novi Sad, +381214853313, rodicv@polj.uns.ac.rs.

3 MSc Danica Glavaš-Trbić, teaching assitant, Faculty of Agriculture Novi Sad, Trg Dositeja Obradovića 8, 21000 Novi Sad,+381214853508,danicagt@gmail.com. 
Strategy of Sustainable Development of Serbia (2007) defines sustainable development as a "goal-oriented, long-term, continuous, comprehensive, and synergistic process that affects all life aspects (economic, social, environmental and institutional) at all levels."

One of the first definitions of sustainable development was given by Repetto, who said that in the core of the sustainability idea lies an assurance that decisions made today should not jeopardize perspectives for preservation or improvement of living standards in the future (Repetto, 1985). If the development is defined as enhancement of well-being, then sustainable development means that there is no reduction in welfare during time (Jovanović-Gavrilović, 2003). Harris (2009) also states that "the road of sustainable development can be understood as the way in which total funds of fixed assets remain the same or increase over time."

When we talk about sustainable development, it is clear that we need to take economic, technological, social, political, physiological and environmental aspects into consideration. These systems are connected in different and often very significant ways in a complex system (Bossel, 1999, Munitlak-Ivanović 2005, Raskin et al., 2002, Rigby et al, 2001b). Today's fast development and industrialization is not very friendly when it comes to sustainability. According to Baćanović (2004), industrial society has never been an "ally" to the environment. She cited Amery (1978) who said that, "Either the industry is going to destroy the environment, or the environment will destroy industrial society."

What needs to be considered when assessing sustainable development is how to determine if development of a certain community or territory is sustainable and based on which quantitative or qualitative indicators can we draw the conclusion on sustainability.

Indicators of sustainable development are the link with reality. They reduced its complexity to a satisfying level of important information, and to small number of sets that assist us in decision making process and directs our actions (Bossel, 1999, Hezri and Dovers, 2006, Moreno Piers et al, 2014). Parris and Kates stated (2003) that a large part of the literature relating to the issues of sustainability suggests that indicators are "led" by the axiom "what gets measured gets managed". Sustainable development indicators should provide us with the information about the system that we are interested in. Since the state of the system is significantly affected by the environment, indicators must reliably represent the connections that exist between the system and its environment. Indicators should make a complex system understandable, and give us meaningful information (van Asselt et al, 2014). Based on the literature review, one can say that both the definition of sustainable development and its indicators are still a bit "confusing". That is why we need to be careful when trying to explain certain indicators, including those related to agriculture. The aim of this paper is to justify the role given to organic agriculture as an indicator and to explain its use in Serbia.

Modern agricultural production, as part of the socio-economic sub-systems, has proven adverse effects on the environment (Rodriguez et al., 2004, Lazić and Lazić, 2008, Kovačević et al., 2011, Pejanović, 2013; Praneetvatakul et al, 2013, Krajewski, 2016, Gomiero, 2018), as a consequence of increasing dependence on the industry (in 
terms of fertilizers and pesticides) and the introduction of monoculture, for the sake of profit. For example, Peyraud et al (2014) argue that one of the main problems of modern agriculture is specialization. They infer that, "Specialized livestock systems and territories face problems of waste disposal leading to nutrient accumulation in the soil (P) and emission of $\mathrm{N}$ to water and air. Meanwhile, territories specialized in cropgrowing face soil impoverishment and have to import mineral fertilizer and pesticides." Hall and Crowther (1998) discuss water pollution with nitrate and pesticides, methane and nitrogen oxide emissions, fossil fuel usage, soil erosion and degradation, reduction of biodiversity etc. as negative environmental impacts of intensive agricultural practices. Some authors (Lewalter and Leng, 1999; Sarkar et al, 2012) found adverse effects of modern agriculture on human health. Casado and Molina (2009) go a step further and argue that conventional agriculture is leading to the loss of income for farmers and thus forcing them to leave agricultural production.

A possible solution of these issues is development of alternative means of agricultural production in order to mitigate their impacts. These alternative means of agricultural production are often categorized as sustainable agriculture. Hinrichs and Welsh (2003) stated that, "Sustainable agriculture offers an encompassing banner under which groups and individuals have gathered to address the environmental, social, and economic equity problems they associate with conventional, industrial agriculture". One of the alternative methods is the system of organic farming. Given the positive aspects of organic production compared to conventional production (Stolze et al., 2005 Kaspercyzk and Knickel 2006, Kichler, 2007, Küstermann et al, 2008, Hinrichs and Welsh, 2003, Biao and Xiaorong, 2003b, Galiardi and Pettigrove, 2013, Bell et al, 2014, Meng et al, 2017), the development of organic agriculture could be and nowadays is seen as an important indicator of sustainable agriculture. Overall it can be said that the aim of the paper was to determine whether the land under organic agriculture can be considered as an indicator of sustainable agricultural development.

\section{Materials and methods}

In this research special focus was on the Republic of Serbia and the current situation was presented. Extensive analysis of existing scientific literature was used to conclude if organic agriculture is sustainable and as such can it be used as an indicator of sustainable development. Descriptive method was used to study the problem, combined with the method of abstraction. With the deduction model, existing theoretical knowledge was considered. Method of induction was used in generalization of the data and conclusion. Secondary sources of literature were used as well as primary data resulting from the research in mentioned projects. 


\section{Results with discussions}

\section{Organic production as an indicator of sustainable agriculture}

Steady growth in population (United Nations, 1992; Azar et al, 1996) has caused an increase in the area used for agricultural production. The increased demand for food has altered the mode of agricultural production. "It is obvious that the conventional (industrial) methods of agricultural production, in addition to providing enough food and other various products, lead to a number of negative, not only environmental but also social and economic consequences" (Kovačević et al., 2011).

Hodge (1993, cit. according to Rigby and Caceres, 2001a) has summarized some negative trends in modern agriculture which led to the review of the long-term sustainability of such production system. According to him, agriculture is put in a position to use inputs from distant sources; an increasing amount of energy from non-renewable sources; depends on fewer gene bases and has an increasing (negative) impact on the environment. This is particularly evident in increasing reliance on chemical industry (in the form of fertilizers and pesticides), dependence on subsidies and price support and increasing externalities, such as habitat disturbance and destruction of various animal and plant species, environmental pollution and risks to human health and welfare.

The simplification of crop rotation (introduction of monocultures) and the growing importance of agricultural technology, synthetic fertilizers and pesticides have led to the fact that agriculture has become one of the main reasons for changes in the habitats of many plants and animals (Knauer, 1993, cit. according to Stolze et al, 2000). Although there is a wide range of understanding and definition of sustainable agriculture, “... there is no doubt that unsustainable farming practices are a reality that urgently needs to be addressed" (Aerni, 2009).

All the negative effects of modern agricultural production, mentioned above, have led to the increase of importance given to other alternative production systems. These alternative systems are primarily characterized by a different approach to the environment. In the context of agricultural production, Ikerd (1993, cit. according to Rigby and Caceres, 2001a) defines sustainable agriculture as a production that has "... the ability to maintain a certain level of productivity and usefulness to society over a long period of time ... it must be suitable for the environment, aimed at conservation of resources, economically and socially sustainable and commercially competitive." Sustainable agriculture is also defined as an "ecologically sound, economically viable, and socially just" (Appleby, 2005) or as a farming method "...concerned with preventing the degradation of some aspect of farm" (Mason, 2003) regardless of whether it is the degradation of natural resources or profitability. Rodić et al. (2008) reported that agricultural land is one of those resources which indicate that "... without sustainable use one cannot talk about sustainable development of agriculture and society as a whole." Hayati et al. (2010) stated that "... sustainable agriculture is a dynamic rather than static concept." 
Organic farming is one of alternative systems of production that is considered to be more suitable for the environment compared to conventional production (Kasperczyk and Knickel, 2006). The often stated reason is that (Rigby and Caceres, 2001a, Mann and Gairing, 2012) organic agriculture dates earlier than the other systems that we call environmentally friendly as well as the rapid growth and development of the organic market in the last decades (Bryła, 2015). Some authors (Stolze et al., 2000; van Elsen, 2000; Kasperczyk and Knickel 2006; Pacini et al., 2003) suggest that organic production systems create acceptable conditions for the development of the ecosystem and the diversity of flora and fauna as compared to conventional systems.

As with sustainable development, organic agriculture has many definitions. Lampkin and Padel (1994) define organic agriculture as "... approach to agriculture where the aim is: to create integrated, human, environmentally and economically sustainable agricultural production systems, which maximize reliance on farm-derived renewable resources and the management of ecological and biological processes and interactions, so as to provide acceptable levels of crop, livestock and human nutrition, protection from pests and diseases, and an appropriate return to the human and other resources employed."

A question which often arises is whether organic farming can be considered a sustainable production system. The literature is full of different explanations - some think that organic production can not feed growing population (Connor, 2018), but in general, the prevailing view is that organic farming is sustainable (Stolze et al., 2000; Kasperczyk and Knickel 2006; Pacini et al., 2003; Kilcher, 2007; Azadi et al, 2011, Delić, 2012, Argyropoulos et al, 2013, Demiryürek et al., 2008, Roljević Nikolić et al, 2017).

When measuring the impact of organic agriculture on the environment, there is the question of indicators and key aspects of sustainability which should be considered and monitored. Stolze et al. (2000) adapted the OECD set of indicators ${ }^{4}$, using only those indicators which are directly related to the organic production system. According to this research, organic agriculture can be considered as environmentally friendly. Patil et al (2014) stated that reasons for considering organic agriculture as sustainable can be found in the fact that organic agriculture requires less financial inputs and places more reliance on the natural and human resources available. This statement is of great importance in countries where farmers have limited financial resources.

In order to achieve self-sufficiency, which is one of the primary principles of sustainability (and organic agriculture), Denmark, for example, decided to phase out the usage of conventional organic and mineral fertilizers in production (Oelfose et al, 2013). They have established a set of governmental strategies that will help the producers to reduce and finally ban the usage of conventional fertilizers and manure. Biao et al. (2003a)

4 For the OECD indicators, Rennings and Wiggering (1997) state that “... these indicators are not related to the objectives of sustainability and provide little information about the most important functions and ecosystem structure. Yet the OECD system can be used as a first step to implementing more advanced indicators in the future. " 
stated that organic agriculture contributes to the sustainability of agriculture through environmentally friendly production, soil fertility, nutrient management, biodiversity and product quality.

As a result of the analysis, the literature states that, despite the disadvantages, organic farming is a sustainable farming system. If the area under organic production increased, the results would entail better agricultural performance in terms of environmental protection and resource use. Organic farming is characterized as a system with less negative impacts (per ha) on the environment and resources compared to conventional production. Therefore, considering an area under organic production system as an indicator of sustainability is reasonable and possible, in combination with other indicators. Consequently, certain regions or states may be characterized as those which more or less follow the way of sustainable development in agriculture.

The ambiguous issue of limits is ever-present, i.e. what total area under organic production or what share of organic production in the total agricultural production of a region/country could be considered sustainable? There is no recipe and it has to be determined (evaluated) with a case-by-case approach, given that every country or a region has its own special features. Besides, it should be noted that some authors (Dantsis et al, 2009) discuss that organic agriculture should not "...aim to evaluate whether a farm is sustainable or not because sustainable development is a process, in which agricultural practices move towards sustainability."

\section{Experiences in the Republic of Serbia}

During the last ten years, Serbia has made significant efforts to address the problems of environmental pollution. Environmental Protection Indicators for Serbia are created according to the methodology of the European Environmental Agency - EEA, based on the comparison between environment and human activity. These relations are presented in the DPSIR model (Driving forces - Pressure - State - Impacts - Responses) where indicators within the model reflect consequential connection (Ministry for Environmental Protection, 2007, Kostić and Rodić, 2009).

The legislative framework for sustainable development, in agriculture and general, has its basis in the Constitution of the Republic of Serbia, which defines the rights of citizens to a healthy environment, and the duty of citizens to protect and improve the environment in accordance with the law. Fundamental laws relating to environmental protection are The Law on Environmental Protection from 2004 (amended in 2009) and the Nature Protection Act from 20095.

5 In addition to the Law on Environmental Protection and Nature Protection Act, other relevant legislation in the field of biodiversity include the Law on Strategic Environmental Impact Assessment (2004), the Law on Environmental Impact Assessment (2004, 2009), the Law on National Parks (1993), the Law on Protection and Sustainable Use of Fish Stocks (2009), and others. 
The national list of indicators for Serbia covers 12 thematic areas: 1) air and climate change, 2) water, 3) nature and biodiversity, 4) soil, 5) waste, 6) noise, 7) non-ionizing radiation, 8) forestry, hunting and fishing, 9) sustainable use of natural resources, 10) social and economic resources and activities relevant to the environment, 11) international and national legislation, and measures (strategies, plans, programs, agreements), reports and other documents and activities related to environmental protection, and 12) entities in the system of environmental protection.

Guided by the above described criteria for indicator selection, the creators of national lists, as one of the indicators in the thematic sections 10 - Social and economic resources and activities relevant to the environment (agriculture), included "areas under organic agriculture ", with two sub-indicators (Table 1):

The total area under organic farming and

Proportion of land area under organic agriculture in the total agricultural area.

Table 1. Area under organic farming indicator

\begin{tabular}{|c|c|}
\hline Theme unit & $\begin{array}{l}10 \text { SOCIAL AND ECONOMIC RESOURCES AND ACTIVITIES } \\
\text { RELEVANT TO THE ENVIRONMENT }\end{array}$ \\
\hline \multicolumn{2}{|l|}{ AGRICULTURE } \\
\hline No. & Name of the indicator \\
\hline 10.67. & 10.67. Area under organic farming \\
\hline The thematic area & Reactions of society \\
\hline $\begin{array}{l}\text { Definition and } \\
\text { description of } \\
\text { indicators }\end{array}$ & $\begin{array}{c}\text { The indicator shows trends of the area under organic farming and its share in } \\
\text { the total agricultural production. Organic farming is sustainable agriculture } \\
\text { which optimally uses soil fertility and available water, the natural properties } \\
\text { of plants and animals, allowing for increased yield and plant resistance } \\
\text { with prescribed (and limited) use of fertilizers and pesticides and animals } \\
\text { protection chemicals. Sub-indicators: } \\
\text { 1. The total area under organic farming; } \\
\text { 2. Proportion of land area under organic agriculture in the total agricultural area. }\end{array}$ \\
\hline $\begin{array}{l}\text { Calculation } \\
\text { methodology and data } \\
\text { collection }^{1}\end{array}$ & $\begin{array}{c}\text { The indicator is prepared on the basis of the data on the total area under } \\
\text { organic farming and its share in the total agricultural area, and it is displayed } \\
\text { numerically in tables and graphs as: } \\
\text { - The share of the area with organic production methods in relation to the } \\
\text { total agricultural area in } \% \text {; } \\
\text { - The share of farms applying organic methods of agriculture in the total } \\
\text { number of farms in } \% \text {; } \\
\text { - The share of allocated incentives for the implementation and development } \\
\text { of organic agriculture in the total amount of incentive in } \% \text {. }\end{array}$ \\
\hline Measure unit & The indicator is expressed in hectares (ha) and percentage (\%). \\
\hline $\begin{array}{l}\text { Legal coverage } \\
\text { with national } \\
\text { and international } \\
\text { regulations and } \\
\text { reporting obligations }\end{array}$ & $\begin{array}{l}\text { - The Law on Organic Production ("Official Gazette of RS", No. 30/10); } \\
\text { - 1804/1999/EEC Council Regulation amending the Regulation on organic } \\
\text { production of agricultural products and labeling of such agricultural products } \\
\text { and foodstuffs, including livestock production; } \\
\text { - Council Regulation } 2092 / 91 / \text { EEC on organic production of agricultural } \\
\text { products and labeling of such agricultural products and foodstuffs; } \\
\text { - European EnvironmentAgency(EEA)-Indicator CSI 026-Area under organic farming. }\end{array}$ \\
\hline
\end{tabular}




\begin{tabular}{|c|c|}
\hline Theme unit & $\begin{array}{l}10 \text { SOCIAL AND ECONOMIC RESOURCES AND ACTIVITIES } \\
\text { RELEVANT TO THE ENVIRONMENT }\end{array}$ \\
\hline $\begin{array}{l}\text { The source and } \\
\text { availability of data } \\
\text { and frequency of data } \\
\text { collection }\end{array}$ & $\begin{array}{c}\text { Ministry of Agriculture, Trade, Forestry and Water Management } \\
\text { Frequency of data collection: annually. }\end{array}$ \\
\hline $\begin{array}{l}\text { Method and deadlines } \\
\text { for data, information, } \\
\text { indicators and reports } \\
\text { to information system }\end{array}$ & Submission deadline: 31 March of the current year for the previous year. \\
\hline
\end{tabular}

Source: Regulation of the national list of environmental protection indicators, Official Gazette of RS 37/2011.

Organic production in Serbia is becoming more popular and economically important. Due to the resources such as soil, which in most cases is not contaminated with heavy metals and organic pollutants, and the fact that organic farming is justified and even valorize successful production on smaller holdings (which dominate in the production structure of the Republic of Serbia (Bogdanov and Rodić, 2014)), this type of agriculture can contribute significantly to the development of rural areas, and thus agriculture in general. Consequently, organic production has been set as a priority of the development of agriculture and is an integral part of the strategy for agricultural and rural development of the Republic of Serbia (Ministry of Energy, Development and the Environment, 2012). The organic production in Serbia is also legally a well-regulated area. In addition to the Law on Organic Production mentioned above, numerous bylaws governing organic agriculture are adopted.

Currently, the organic agriculture in the Republic of Serbia is underdeveloped. According to the official data of the Serbian Ministry of Agriculture, in 2015 there were 15,298 hectares in the organic production system in the country, as presented in Table 2.

Table 2. Organic area (certified organic + in-conversion) in Serbia in 2015

\begin{tabular}{|c|c|}
\hline Production type & $\begin{array}{c}\text { Certified organic area + in- } \\
\text { corversion area (ha) }\end{array}$ \\
\hline Crop production & 4,252 \\
\hline Fruit production & 2,895 \\
\hline Industrial plant & 2,674 \\
\hline Forage & 1,440 \\
\hline Vegetable production & 170.5 \\
\hline Medicinal and aromatic plants & 71 \\
\hline Other & 1,895 \\
\hline Total & 15,298 \\
\hline
\end{tabular}

Source: Ministry of Agriculture and Environment. Directorate for national reference laboratories

Since 2010, the areas under organic management showed modest growth, as shown in Table 3. 
Table 3. Organic area in Serbia 2010-2015

\begin{tabular}{|c|c|c|c|c|c|c|}
\hline Years & $\mathbf{2 0 1 0}$ & $\mathbf{2 0 1 1}$ & $\mathbf{2 0 1 2}$ & $\mathbf{2 0 1 3}$ & $\mathbf{2 0 1 4}$ & $\mathbf{2 0 1 5}$ \\
\hline $\begin{array}{c}\text { Areas under } \\
\text { organic } \\
\text { management (ha) }\end{array}$ & 5,855 & 6,335 & 6,340 & 8,228 & $9,547.8$ & 15,298 \\
\hline
\end{tabular}

Source: Ministry of Agriculture and Environment. Directorate for national reference laboratories

According to the Census of Agriculture, the total utilized agricultural area (UAA) in Serbia is 3.355.859 ha, which means that the share of organic area in the total UAA is $0,45 \%$, whereas in the EU-27 in 2011 the total organic area amounted to an estimated $5.4 \%$ of the total UAA (EC, 2013).

The situation is not much better when it comes to organic animal sector. According to the same sources and Simić (2017) there are in total 2,984 organic bovine heads (cattle, buffaloes, horses, donkeys), 6,766 organic small livestock heads (sheep, goats, pigs), 1,380 organic poultry (chickens, geese, ducks, turkeys, guinea fowls) and 2,504 organic beehives in Serbia. Due to the lack of data, which allows comparison between the different types of animals (number of organic livestock units), the conclusion on the share of organic in the total animal heard in Serbia cannot be deduced, but it is for sure far from the level in the EU-27 (which is about 1\%).

Therefore, if organic agriculture is solely used as an indicator of sustainable agricultural development, it is highly debatable whether the Serbian agriculture can be considered sustainable. It is true that the above-stated number of hectares does not include area used for the collection of wild berry fruits, mushrooms and medicinal herbs (since there is such practice in Serbia, but there is no official methodology based on which reliable data can be obtained) and that in reality the situation is not as bad as it looks according to the official data. Nevertheless, one can say that there is still a lot of room for sustainability improvement in Serbia, at least regarding organic agriculture as one of its indicators.

Admittedly, none of the indicators by itself is sufficient for assessing sustainability. Thus, in order to obtain a more complete picture about agricultural sustainability, organic production should be considered in conjunction with the indicators from the other thematic units (such as soil, consumption of fertilizers and pesticides, etc.).

\section{Conclusions}

There are many definitions of sustainable development in the literature. The main differences arise from the authors' conception of sustainability, the expression of sustainability, and primarily the time horizon in which the sustainability is measured. A reliable indicator is one that points to a problem before it becomes too serious and it helps to understand what should be done to resolve the problem. Sustainable development indicators indicate where the cause-effect relationship between the economy, environment and society is weak and show us guidance on how to solve these problems. 
Negative trends that follow the conventional agricultural production, in terms of its impact on the environment, have led to the questioning of this concept of production and the search for other forms, which will have less negative impact. Organic farming is among so-called sustainable agricultural systems. After measuring the impact of organic farming on the environment, the prevailing view in the literature is that organic farming can be considered sustainable. For this reason, the area under organic farming systems in a particular region may contribute to a better understanding of the development of that region. In combination with other indicators of sustainable agriculture, the area under organic production would help in assessing agricultural production and land use in terms of sustainability.

In Serbia, the share of the organic area in the UAA is relatively low, only around $0.45 \%$, thus based solely on this indicator agricultural sustainability cannot be positively assessed. Perhaps the better "image" of sustainability would be obtained if the indicator was observed in conjunction with other indicators, which exceeds the scope of this paper.

If we accept the opinions of Moran et al. (2008) that measurable results, rather than intentions, determine whether mankind is moving on the path of sustainable development, we can say that quantification of human development and environmental sustainability is, to some extent, possible with the currently available indicators, but we must continue to develop them in future. Despite some claims that sustainable development is an elusive concept, one could say that the minimum conditions for sustainable development (and sustainable agriculture) can be measured. In this light, organic agriculture in Serbia is showing a rather "slow" process of development, which leads to a conclusion that more has to be done on macroeconomic level, related to this subject.

Moreover, one should also bear in mind what John Ikerd once said (quoted according to Goldberger, 2011): "Sustainable agriculture is a question rather than an answer... It is a direction rather than destination, like a star that guides the ships at sea but remains forever beyond horizon. The question of sustainability can be asked of any ongoing activity or process, including conventional agriculture and any proposed alternative." In other words, sustainable agriculture is a long-term goal (a "direction") not a set of specific farming practices."

\section{Acknowledgements}

The paper is a part of research projects No TR 31095, OI 179028 and III 46006 financed by the Ministry of Education, Science and Technological Development of the Republic of Serbia.

\section{Conflict of interests}

The authors declare no conflict of interest. 


\section{References}

1. Aerni, P. (2009). What is sustainable agriculture? Empirical evidence of diverging views in Switzerland and New Zealand. Ecological Economics 68: 1872-1882, doi:10.1016/j.ecolecon.2008.12.016

2. Appleby, M. (2005). Sustainable agriculture is humane, humane agriculture is sustainable. Journal of Agricultural and Environmental Ethics 18: 293-303, DOI 10.1007/s10806-005-1490-9

3. Argryopoulos, C., Tsiafouli, M., Sgardelis, S., \& Pantis, J. (2013). Organic farming without organic products. Land Use Policy 32: 324-328.

4. Azadi, H., Schoonbeek, S., Mahmoudi, H., Derudder, B., De maeyer, P., \& Witlox F. (2011). Organic agriculture and sustainable food production system: Main potentials. Agriculture, Ecosystems and Environment 144: 92-94, doi:10.1016/j. agee.2011.08.001

5. Azar, C., Holmberg, J., \& Lindgren K. (1996). Socio-ecological indicators for sustainability. Ecological Economics 18: 89-112.

6. Baćanović, D. (2004): Indicators of sustainable development and assessment of the level of sustainability of AP Vojvodina development. doctoral dissertation, ACIMSI Environmental Engineering. Novi Sad (in Serbian: Indikatori održivog razvoja i procena nivoa održivosti razvoja AP Vojvodine, doktorska disertacija, ACIMSI Inženjerstvo za zaštitu životne sredine).

7. Bell, M.J., Cloy, J.M., \& Rees, R.M. (2014). The true extent of agriculture's contribution to national greenhouse gas emission. Environmental Science \& Policy 39:1-12, http://dx.doi.org/10.1016/j.envsci.2014.02.001

8. Bell, S., \& Morse, S.(2003). Measuring sustainability-learning by doing. Earthscan Publication Limited, London.

9. Biao, X., Xiaorong, W., Zhuhong, D., \& Yaping Y. (2003a). Critical impact assessment of organic agriculture. Outlook on Agriculture 38(3): 161-164.

10. Biao, X., \& Xiaorong, W. (2003b). Organic agriculture in China. Journal of Agriculture and Environmental Ethics 16: 297-311.

11. Bogdanov, N., \& Rodić, V. (2014). Agriculture and Agricultural Policy in Serbia. Chapter B. VII in: Agricultural Policy and European Integration in Southeastern Europe Ed. by Volk, T., Erjavec, E.,\& Mortensen, K., FAO, Budapest pp. 153171, ISBN 978-92-5-108612-4

12. Bossel, H. (1999). Indicators for Sustainable Development: Theory, Method, Applications. A Report to the Balaton Group. International Institute for Sustainable Development. Winnipeg, Canada.

13. Bryła, P. (2015). The Development of Organic Food Market as an Element of Sustainable development Concept Implementation. Problems of Sustainable Development 10(1): 79-88. 
14. Casado, G., \& De Molina, G. (2009). Preindustrial agriculture versus organic agriculture - The land cost of sustainability. Land Use Policy 26: 502-510.

15. Connor, D. J. (2018). Organic agriculture and food security: a decade of unreason finally implodes. Field Crops Research, 225, 128-129.

16. Demiryürek, K., Stopes, C., \& Güzel A. (2008). Organic agriculture: the case of Turkey. Outlook on Agriculture 37(4): 261-267.

17. Dantsis, T., Loumou, A., \& Giourga C. (2009). Organic Agriculture's Approach towards Sustainability; Its Relationship with Agro-Industrial Complex, A Case Study in Central Macedonia, Greece. J Agric Environ Ethics 22: 197-216.

18. Delić, S. (2012). Factors of sustainable development of agriculture of AP Vojvodina, doctoral dissertation, University of Novi Sad, Faculty of Agriculture. (in Serbian: Faktori održivog razvoja poljoprivrede AP Vojvodine, doktorska disertacija, Univerzitet u Novom Sadu, Poljoprivredni fakultet.).

19. Galiardi, B., \& Pettigrove, V. (2013). Removal of intensive agriculture from landscape improves aquatic ecosystem health. Agriculture, Ecosystem and Environment 176: 1-8, http://dx.doi.org/10.1016/j.agee.2013.05.020

20. GIZ (2014). Organic agriculture in Serbia 2014, National Association „Serbia Organica“, Beograd.

21. Goldberger, J.R. (2011). Conventionalization, civic engagement, and the sustainability of organic agriculture. Journal of Rural Studies 27: 288-296.

22. Gomiero, T. (2018). Agriculture and degrowth: State of the art and assessment of organic and biotech-based agriculture from a degrowth perspective. Journal of Cleaner Production, 197, 1823-1839.

23. EC - European Commission (2013). Facts and figures on organic agriculture in the European Union, DG Agriculture and Rural Development, Unit Economic Analysis of EU Agriculture.

24. Hall, J., \& Crowther, S. (1998). Biotechnology: the ultimate cleaner production technology for agriculture? Journal of Cleaner Production 6: 313-322.

25. Harris, J. (2009). Economics of Environment and Natural Resources Contemporary Approach, Datastatus, Belgrade (in Serbian: Ekonomija životne sredine i prirodnih resursa-savremeni pristup, Datastatus, Beograd).

26. Hayati, D., Rajnbar, Z., \& Karami E. (2010). Measuring Agricultural Sustainability in Lichfouse E. (ed.). Biodiversity, Biofuels, Agroforestry and Conservation Agriculture, Sustainable Agriculture Reviews 5.

27. Hezri, A., \& Dovers, S. (2006). Sustainability indicators, policy and governance: Issues for ecological economics. Ecological Economics 60: 86-99, doi:10.1016 /j.ecolecon.2005. 11.019

28. Hinrichs, C., \& Welsh, R. (2003). The effects of the industrialization of US livestock agriculture on promoting sustainable production practice. Agriculture and Human Values 20: 125-141. 
29. Ikerd, J.E. (1993). Two related but distinctly different concepts. Small Farm Today. USA.

30. Jovanović-Gavrilović, B. (2003). Sustainable Development - Conceptual and Methodological Issues, Ecologica 10: 39-40 (in Serbian: Održivi razvoj konceptualna i metodološka pitanja, Ecologica 10: 39-40).

31. Kaspercyzk, N., \& Knickel, K. (2006). Environmental impacts of organic farming in Kristiansen, P., Taji, A., Reganold, J.: Organic Agriculture A Global Perspective, CABI, United Kingdom, pp. 259-295.

32. Kates, R., Parris, T., \& Leiserowitz, A. (2005). What is Sustainable Development? Goals, Indicators, Values, and Practice. Environment: Science and Policy for Sustainable Development 47 (3): 8-21.

33. Krajewski, P. (2016). Agricultural Biodiversity for Sustainable Development. Problems of Sustainable Development 12(1): 135-141.

34. Kilcher, L. (2007). How organic agriculture contributes to sustainable development. JARTS. Supplement 89. University of Kassel at Witzenhausen, Germany, pp. 31-49.

35. Kostić, S, \& Rodić, V. (2009). The P-S-R Framework and its modified (extended) versions as the environmental management means. Proceedings of XIII International ECO-conference „Environmental Protection of Urban and Suburban Settlements “. Novi Sad, 23-26 September 2009, pp. 429-436.

36. Kovačević, D., Lazić, B., \& Milić, V. (2011). The impact of agriculture on the environment. International Scientific Meeting of Agronomists. Jahorina (in Serbian: Uticaj poljoprivrede na životnu sredinu. Međunarodi naučni skup agronoma. Jahorina).

37. Küstermann, B., Kainz, M., \& Hülsbergen, K.J. (2008). Modeling carbon cycles and estimation of greenhouse gas emission from organic and conventional farming systems. Renewable Agriculture and Food Systems 23(I): 38-52.

38. Lampkin, N., \& Padel, S. (1994). The Economics of Organic Farming, an International Perspective. $C A B$ International, London.

39. Lazić, B., \& Lazić S. (2008). Organic Agriculture in Lazić B. et al .: Organic Agriculture, Institute of Field and Vegetable Crops (in Serbian: Organska poljoprivreda u Lazić B. i sar.: Organska poljoprivreda, Institut za ratarstvo i povrtarstvo) Novi Sad, str. 7-38.

40. Lele, S. (1991). Sustainable Development: A Critical Review. World Development 19 (6): 607-621.

41. Lewalter, J., \& Leng, G. (1999). Consideration of individual susceptibility in adverse pesticide effects. Toxicology Letters 107: 131-144.

42. Mann, S., \& Gairing, M. (2012). "Loyals" and "Optimizers": Shedding Light on the Decision for or Against Organic Agriculture Among Swiss Farmers. J Agric Environ Ethics 25: 365-376, DOI 10.1007/s10806-011-9309-3 
43. Mason, J. (2003). Sustainable Agriculture, Landlinks Press, Australia.

44. Meng, F., Qiao, Y., Wu, W., Smith, P., \& Scott, S. (2017). Environmental impacts and production performances of organic agriculture in China: A monetary valuation. Journal of environmental management, 188, 49-57.

45. Ministry of Energy, Development and Environmental Protection (2012). Environmental Report of the Republic of Serbia for 2011. Environmental Protection Agency. Belgrade.(in Serbian: Izveštaj o stanju životne sredine u Republici Srbiji za 2011. godinu, Agencija za zaštitu životne sredine, Beograd).

46. Moran,, D., Wackernagel, M., Kitzes, J., Goldfinger, S., \& Boutaud, A. (2008). Measuring sustainable development — Nation by nation. Ecological Economics 64: 470-474, doi:10.1016/j.ecolecon.2007.08.017

47. Moreno Piers, S., Fidélis, T., \& Ramos, T. (2014). Measuring and comparing sustainable development through commonindicators: Constrains and achievements in practice. Cities 39: 1-9, http://dx.doi.org/10.1016/j.cities.2014.02.003

48. Munitlak-Ivanović, O. (2005). Ecological Aspects of Sustainable DevelopmentInternational and Regional Comparison, Doctoral Dissertation, Faculty of Economics, Subotica. (in Serbian: Ekološki aspekti održivog razvoja-međunarodna i regionalna komparacija, doktorska disertacija, Ekonomski fakultet, Subotica).

49. National Sustainable Development Strategy, "Official Gazette of RS”, no. 55/05, 71/05 - and correction 101/07. (in Serbian: Nacionalna strategija održivog razvoja, „Službeni glasnik RS”, br. 55/05, 71/05-ispravka i 101/07).

50. Oelfose, M., Stoumann Jensen, L., \& Magid, J. (2013). The implications of phasing out conventionl nutrient supply in organic agriculture: Denmark as a case. Org. Agr. 3: 41-55, DOI 10.1007/s13165-013-0045-z

51. Pacini, C., Wossink, A., Giesen, G., Vazzana, C., \& Huirne, R. (2003). Evaluation of sustainability of organic, integrated and conventional farming systems: a farm and field scale analysis in Pacini, C.: An environmental-economic framework to support multi-objective policy-making-a farming systems approach implemented for Tuscany, University of Florence, Italy and Wageningen University, str. 27-47.

52. Parris, T., \& Kates, R. (2003). Characterizing and measuring sustainable development. Annu. Rev. Environ. Resour. 28:13.1-13.28, doi: 10.1146/annurev. energy.28.050302.105551

53. Patil, S., Reidsma, P., Shah, P., Purushothaman, S., \& Wolf, J. (2014). Comparing conventional and organic agriculture in Karnataka, India: Where and when can organic farming be sustainable. Land Use Policy 37: 40-51.

54. Pejanović, R. (2013). Views on the agricultural and rural economy, Faculty of Agriculture, Novi Sad. (in Serbian: Ogledi iz agrarne i ruralne ekonomije, Poljoprivedni fakultet). 
55. Peyraud, J.L., Taboada, M., \& Delaby, L. (2014). Integrated crop and livestock systems in Western Europe and South America: A review. Europ. J. Agronomy 57: 31-42, http://dx.doi.org/10.1016/j.eja.2014.02.005

56. Rulebook on the National List of Environmental Indicators, "Official Gazette of $R S^{\prime \prime}$ no. 37/2011. (in Serbian: Pravilnik o nacionalnoj listi indikatora zaštite Životne sredine, ,Službeni glasnik RS“ br. 37/2011).

57. Praneetvatakul, S., Schreinemachers, P., Pananurak, P., \& Tipraqsa, P. (2013). Pesticides, external costs and policy options for Thai agriculture. Environmental Science \& Policy 27: 103-113, http://dx.doi.org/10.1016/j.envsci.2012.10.019

58. Raskin, P., Banuri, T., Gallopin, G., Gutman, P., Hammond, A., Kutes, R., \& Swart, R. (2002). Great Transition. SEI, Stockholm.

59. Rennings, K., \& Wiggering, H. (1997). Step towards indicators of sustainable development: Linking economic and ecological concepts. Ecological Economics 20: 25-36.

60. Reppeto, R. (1985). The Global Possible-Resources, Development and New Century. World Resources Institute Book, Yale University Press, New Haven, 1985.

61. Rigby, D., \& Caceres, D. (2001a). Organic farming and the sustainability of agricultural systems. Agricultural Systems 68: 21-40.

62. Rigby, D., Woodhouse, P., Young, T., \& Burton, M. (2001b). Constructing a farm level indicator of sustainable agricultural practice. Ecological Economics 39: 463-478.

63. Rodić, V., Bošnjak, D., \& Vukelić, N. (2008). Sustainability of agricultural land management in AP Vojvodina. Agroekonomika. (in Serbian: Održivost upravljanja poljoprivrednim zemljištem u AP Vojvodini) vol. 37-38, str. 15-23.

64. Roljević Nikolić, S., Vuković, P., Grujić, B. (2017). Measures to Support the Development of Organic Farming in the EU and Serbia. Economics of Agriculture 64(1), 323-337.

65. Rodriguez, E., Sultan, R., \& Hilliker, A. (2004). Negative Effects of Agriculture on Our Environment. Ef Agric Traprock, 3, pp. 28-32.

66. Sarkar, A., Aronson, K.J., Patil, S., Hugar, L.B., \& Vanloon. G.W. (2012). Emerging health risks associated with modern agricultural practices: A comprehensive study in India. Environmental Research 115: 37-50, http://dx.doi.org/10.1016/j. envres.2012.03.005

67. Simić, I. (2017). Organic agriculture in Serbia 2017, National Organization Serbia Organica. (in Serbian: Organska poljoprivreda u Srbiji 2017, Nacionalno udruženje za razvoj organske proizvodnje Serbia Organica) Beograd.

68. Stolze, M., Piorr, A., Haring, A., \& Dabbert, S. (2000). Environmental impacts of organic farming in Europe. Organic Farming in Europe: Economics and Policy, Department of Farm Economics. University of Hohenheim. Germany. 
69. UN-United Nations (1987). Report of the World Commission on Environment and Development: Our Common Future.

70. UN-United Nations (1992). Long-range World Population Projections, Two Centuries on Population Growth 1950-2050. Department of International and Social Affairs, United Nations. New York.

71. UNEP-United Nation Environmental Program (2013). Embedding the Environment in Sustainable Development Goals, UNEP Post-2015 Discussion Paper 1, available at http://www.unep.org/pdf/embedding-environments-inSDGs-v2.pdf

72. Van Asselt, E.D., Van Bussel, L.G.J., Van Der Voet, H., Van Der Heijden, G.W.A.M., Tromp, S.O., Rijgersberg, H., Van Evert, F., Van Wagenberg, C.P.A., \& Van Der Fels-Klerx, H.J. (2014). A protocol for evaluating the sustainability of agri-food production systems - A case study on potato in peri-urban agriculture in The Netherlands. Ecological Indicators 43: 315-321, http://dx.doi.org/10.1016/j. ecolind.2014.02.027

73. Van Elsen, T. (2000). Species diversity as a task for organic agriculture in Europe. Agriculture, Ecosystems and Environment 77: 101-109. 